\title{
IAMJ
}

INTERNATIONAL

AYURVEDIC

MEDICAL JOURNAL

ISSN: 2320-5091

Impact Factor: 6.719

\section{PREPARATION OF AQUEOUS EXTRACT OF TINOSPORA CORDIFOLIA (WILD) MIERS EX. HOOK F. \& THOMS.: AN AYURVEDA FORMULATION}

\author{
Vijay Kumar Jatoliya ${ }^{1}$, Govind Sahay Shukla ${ }^{2}$, Rajaram Agarwal ${ }^{3}$, Manisha Goyal ${ }^{4}$ \\ ${ }^{1}$ M.D. Scholar (P.G. Department of Rasashastra \& Bhaishjya Kalpana) \\ ${ }^{2}$ Prof. \& H.O.D. (P.G. Department of Rasashastra \& Bhaishjya Kalpana) \\ ${ }^{3}$ Asso. Prof. (P.G. Department of Rasashastra \& Bhaishjya Kalpana) \\ ${ }^{4}$ Asso. Prof. (P.G. Department of Rasashastra \& Bhaishjya Kalpana) \\ Dr. Sarvapalli Radhakrishanan Rajasthan Ayurveda University, Jodhpur, Rajasthan, India
}

Corresponding Author: vijayjatolia93@gmail.com

\section{https://doi.org/10.46607/iamj0209082021}

(Published Online: August 2021)

Open Access

(C) International Ayurvedic Medical Journal, India 2021

Article Received: 04/07//2021 - Peer Reviewed: 11/07/2021 - Accepted for Publication: 15/07/2021

Check for updates

\begin{abstract}
Guduchi is an important Rasayan drug in Ayurveda. It is used different dosage forms to cure diseases. Guduchi is described in our classics to cure the various types of diseases i.e., Kamala, prameha, vatrakata, etc. it is used by the patient there in a suitable form. So, the requirement of the patient and good palatable, it is converted into a suitable form by using various types of methods. In Ayurveda, five major Kalpana which are called Pancvidha Kashaya Kalpana is described first in Charak Samhita. Another minor Kalpana like vati, churna, ghana, sandhan Kalpana is derived from panchvidha kashaya Kalpana. Guduchi Ghana is an important and unique preparation of Ayurveda. It is prepared from an aqueous extract of Guduchi. It is the secondary Kalpana which is derived from the primary Kalpana kwatha. In the present study preparation of Guduchi Ghana according to classical text "Siddha Yoga Sangraha” by Acharya Yadavji Trikamji. Guduchi is a soft drug so, water has been taken for the preparation of kwatha is four-time to Guduchi Dravya. When a confirmatory test of kwatha or reduced 1/4, it was filtered with the help of the cloth. After filtered, it was kept on the heat for preparation of Ghana. End of the whole procedure, the dark brown and sticky nature of Ghana was obtained. It is bitter and not specific smell. It has taken 5-6 hrs to complete the process. In the initial raw material has been taken $1.5 \mathrm{~kg}$ and the final product is obtained about $105 \mathrm{gm}$.
\end{abstract}

Keywords: Guduchi, Rasayan, Prameha, Kashaya Kalpana, Kwatha. etc. 


\section{INTRODUCTION}

Ayurveda is a science of medicine that cures diseases. Ayurveda medicine was used by people from the ancient period. Ayurveda science has been framed upon Trisutra i.e., Hetu, Linga, Aushadha. All of them Aushadha is very important, and it is responsible for a treat the diseases which also maintain the good and promote health. With the skill of the formulation, a poisonous drug can be converted into a safe and effective drug. In the formulation, a simple drug is transmuted into the most potent drug. Thus Ayurveda, the science of health and healing has given great emphasis to the comprehensive knowledge of the drugs, preserve, and dispensing of a prepared drug under the broad heading known as Rasashastra and Bhaishjya Kalpana. Rasashastra is a branch of pharmacy which deal with the study chemical substance which is used as medicines, their detoxification, and processing, etc. In short, Rasashastra means Ayurvedic pharmaceutics which deals mainly with drugs of mineral origin their varieties, characteristics, processing techniques, properties, and their therapeutics uses along with descriptions of various apparatus, different kinds of furnaces, heating devices, and heating schedules. Bhaishjya Kalpana consists of words Bhaishyya deals with drugs and Kalpana deals with processing. Thus, Bhaishjya Kalpana is the pharmaceutics branch which deals with various types of medicinal preparations, their formulations, dosage form, etc. processing which are established for changes in the properties of the drug either inducing a new property or improving the existing one and finally making the drug safe for use and more effective. Any substance or herb may be called Bheshaja if it can mitigate the diseases. Kalpana means "Yojana" or planning or an ideology that making use of different dravyas. It is prepared to form like swarasa, kwatha, etc. Thus, Kalpana is a process through which a substance is converted into a medicinal form. This complete process of drugs including procurement, identification, processing, and preparation under a separate branch is called Bhaishjya Kalpana. Five basic formulations are used to prepare medicines from herbs in Ayurveda i.e., swarasa kalka, kwatha, hima, phanta. Word Kashaya means is a distortion of the original shape of dravya and making it suitable for use. There are Panchvidha Kashaya Kalpana are described in Ayurveda classics. Their anukalapana are also well defined in Ayurveda i.e., Churna, Vati, Sandhan Kalpana, Sneha Kalpana, Ghansatwa, etc. Guduchi is an important drug for therapeutic use. It is used in different forms like Swarasa, Taila, Ghrita, etc. Guduchi Ghana is first described in Ayurveda classic "Siddha Yoga Sangrah" as the name of Sanshamani Vati by Yadavji Trikamji. Specially mention for jwara treatment.

Guduchi Ghana is an important preparation in Ayurveda classics. It is used in various types of diseases like fever, gout, jaundice, indigestion, and general weakness. Tinospora cordifolia an important medicinal plant is also known as Guduchi. It is widely distributed in India, extending from the Himalayas down to the southern part of peninsular India. It is categorized as "Rasayana" and used for its anti-inflammatory, immunomodulatory, anti-allergic, anti-diabetic, properties, etc. The whole plant is used medicinally; however, the stem is approved for use in medicine as listed by the Ayurvedic Pharmacopoeia of India. This is due to higher alkaloid content in the stems than in the leaves. Guduchi Ghana which is a concentrated form of the decoction is the secondary Kalpana which is derived from primary Kalpana i.e., kwatha.

\section{Guduchi}

Botanical name - Tinospora cordifolia (Wild) Miers ex. Hook f. \& Thom's - Menispermaceae

\section{Vernacular Names}

Sanskrit - Guduchi, Madhuparni, Amrita, Chhinnaruha, Tantrika, Chakrlakshini, Kundalini, Hindi Giloy, Gudich, Bangali - Gulunch, Malyalam - Gulbela, Gujarati - Galo, Telagu - Tippatigo, Arabi Gulunch

\section{Pharmacological properties}

Rasa - Tikta, Kashaya, Guna - Guru, Snigdha, Virya Ushna, Vipaka - Madhura 
Chemical Composition: Guduchi is highly rich in Antioxidants: It has wound-healing properties, antipyretic (fever-reducing), and anti-viral properties.

Alkaloids: Berberine, Choline, Tembetarine, Magnoflorine, Tinosporin, Palmetine, Isocolumbin, Aporphine alkaloids, Jatrorrhizine, Tetrahydropalmatine. Diterpenoid Lactones: Furanolactone, Clerodane derivatives[(5R,10R)-4R-8R dihydroxy-2S-R:15,16- diepoxy-cleroda-13 (16),14-dieno-17,12S:18,1S dilactone], Tinosporon, Tinosporides, Jateorine, Columbin

Glycosides: 18-norclerodane glucoside, Furanoid diterpene glucoside, Tinocordiside, Tinocordifolioside, Cordioside, Cordifolioside, Syringin, Syringin apiosylglycoside, Pregnane glycoside, Palmatosides, Cordifolioside A, B, C, D, E

Steroids: Beta-sitosterol, Delta -sitosterol,20 Beta-hydroxyecdysone, Ecdysterone, Makisterone A, Giloinsterol

Sesquiterpenoid: Tinocordifolin Aliphatic compound: Octa-cosanol, Hepta-cosanol Nonacosan-15one dichloromethane Others: 3-(4-Dihydroxy-3-methoxy-benzyl)-4-(4-compounds hydroxy-3-methoxybenzyl)-tetrahydrofuran, Jatrorrhizine, Tinosporidine, Cordifol, Cordifelone, Giloinin, Giloin, N-transferuloyltyramineas diacetate, Tinosporic acid

Antioxidants: Ascorbic acid, Lycopene, Carotene, Phenol, Iron, Anthocyanin

\section{Aim and Objectives}

- Preparation of the Guduchi Ghan according to classical text.

- Evaluate the pharmaceutics study during preparation.

Material and Method: For the preparation of Guduchi Ghan, the stems of the Guduchi were collected from the college campus and identified by RS\&BK departmental Staff.

Pharmaceutics of Guduchi Ghan Vati

\section{A. Preparation of Guduchi Kwatha}

Green Guduchi stems were washed with water and then hammered and cut into small pieces of size 1.5 to 2.5 inches. After some time, it was heated on the gas stove with water which was taken 4 times to the Guduchi Dravya on mild heat \& stirring without covering the mouth of the vessel. Water was evaporated slowly and reduced till the quantity remain $1 / 4$ th part. After it, the heating process was ceased and allowed to filter through single fold fresh cloth. This filtered Kwatha was collected as Guduchi Kwatha. A total of 4 times of water was used for $1.5 \mathrm{~kg}$ of fresh Guduchi. Initially, the raw materials floated over the surface of the menstruum, which gradually settled down after 1.5 hours of heating. Evaporation started, which was aggravated by stirring. The menstruum was light brownish green colour in the initial stage, which gradually turned to dark green. All vessels had been washed and cleaned properly before being used.

Table 1: Organoleptic parameter of Guduchi kwatha

\begin{tabular}{|r|l|l|}
\hline S.No. & Parameter & Result \\
\hline $\mathbf{1 .}$ & Colour & Greenish brown \\
\hline $\mathbf{2 .}$ & Odour & Characteristic \\
\hline $\mathbf{3 .}$ & Taste & Bitter \\
\hline $\mathbf{4 .}$ & Touch & Liquid and sticky \\
\hline
\end{tabular}

\section{B. Preparation of Guduchi Ghana}

Now prepared Guduchi Kwatha was taken in a steel vessel and the heating process was carried out on the gas stove with stirring till it converted into semi-solid mass form. Then the heating process was stopped and taken into a steel tray and kept in sunlight till complete drying. After 3-4 hrs, it was dried. Now it was scraped with the help of a scraper. That dried Ghana was collected as Guduchi Ghana. 
Table 2: Organoleptic parameters of Guduchi Ghana

\begin{tabular}{|r|l|l|}
\hline S.No. & Parameter & Result \\
\hline $\mathbf{1 .}$ & Colour & Dark brown \\
\hline $\mathbf{2 .}$ & Odour & Not specific \\
\hline $\mathbf{3 .}$ & Taste & Bitter \\
\hline $\mathbf{4 .}$ & Touch & Liquid and more sticky \\
\hline
\end{tabular}

\section{Observation}

- In starting phase liquid was light brown.

- In this phase, the raw material was floated over the surface which was settled down after an average of 1.30 hours.

- After continuous, this stage about 3 hours later colour of liquid become dark green.

- After 4 hours of boiling, mild sticky nature was observed on rubbing between two fingers.

- After 5 hours of heating, the stickiness of the liquid and adhesiveness to the vessels was found to be increased.

- After drying in the steel tray, brownish-green coloured and semi-solid material was converted into brown coloured solid material.

- Continuous stirring of Kwatha was done to avoid its burning.

- The temperature was maintained on medium fire. During the final stage, mild heat was given, and continuous stirring was done to avoid adhesiveness to the vessel.

- To protect the material from direct heating, it was transferred into a steel tray for drying.

- To remove the water content completely, the drying process was done in steel at between $50^{\circ} \mathrm{C}$ temperature for 2-3 hours.

- After 3 hours, it was scraped with the help of a scraper.

\section{Precaution}

- Raw material should be free from dust and other unwanted material.

- Guduchi should be taken in small pieces.

- Guduchi piece should be taken in finger shape.

- Kwatha should be made on moderate fire.

- Cloth for the poured to the kwatha should be clean and washed.
- At the time of adhesiveness, the fire should be down and stir continuously.

- Measurement should be noted carefully.

\section{DISCUSSION}

Drug Guduchi was collected in April month because more extraction is found out at this time. Fresh Guduchi stem has been taken for the preparation which is described in classics. It is a perennial shrub, so it is easily available every season. Before the preparation of Guduchi Ghana, physical impurities have been separated. The size of the Guduchi pieces has been taken to find out better extraction. The first postharvest processing includes primary cutting which is "Angushtha Pramana". The diameter of the stem is about $1.5 \mathrm{~cm}$ to $2.0 \mathrm{~cm}$. has been taken for the preparation. In Charaka Samhita Kalpa Sthana, Swarasa (fresh Juice) is subjected for heating, instead of Kwatha (decoction) and it is boiled till it becomes semisolid and then subjected for complete drying. When the decoction is boiled till it becomes completely dry i.e., Ghana. In the present study, Guduchi Ghana was prepared. Average $1.5 \mathrm{~kg}$ of fresh Guduchi stem, already cut into the size of 1.5 to 2.0 inches were taken with the 4 times of water and Kwatha was prepared which was further heated to procure final Ghana. The average time taken for the Ghana preparation was 5-6hrs. The average quantity of Ghana obtained in wet condition was $110 \mathrm{gm}$ and after drying it was turned to average $105 \mathrm{gm}$.

\section{CONCLUSION}

Guduchi is an important drug to cure many diseases in different forms. So, it is widely used in the treatment of diseases like jwara, kamala, shotha, shwetapradar, prameha, mandagni, dorbalya, etc. it is bitter so, it may be taken in different form like swarasa, kwatha, taila, vati, churna, etc. Guduchi Ghana is a semisolid 
form that is the secondary preparation of kwatha. Guduchi ghana preparation is a major procedure. In the present study, Guduchi Ghan has been made according to the classical text "Siddha Yoga Sangrah" written by Acharya Yadavji Trikamji. In the formulation, fresh Guduchi stem which is more extract has been taken. Guduchi stem was crushed to find out better extraction. Now it was kept with four-time of water on mild fire. Prepared kwatha was filtered with help of the cloth. Now obtained kwatha was kept in a vessel for preparation of Guduchi Ghana. Finally, we obtained Guduchi Ghana is $105 \mathrm{gm}$ which was taken $1.5 \mathrm{~kg}$ fresh Guduchi stem.

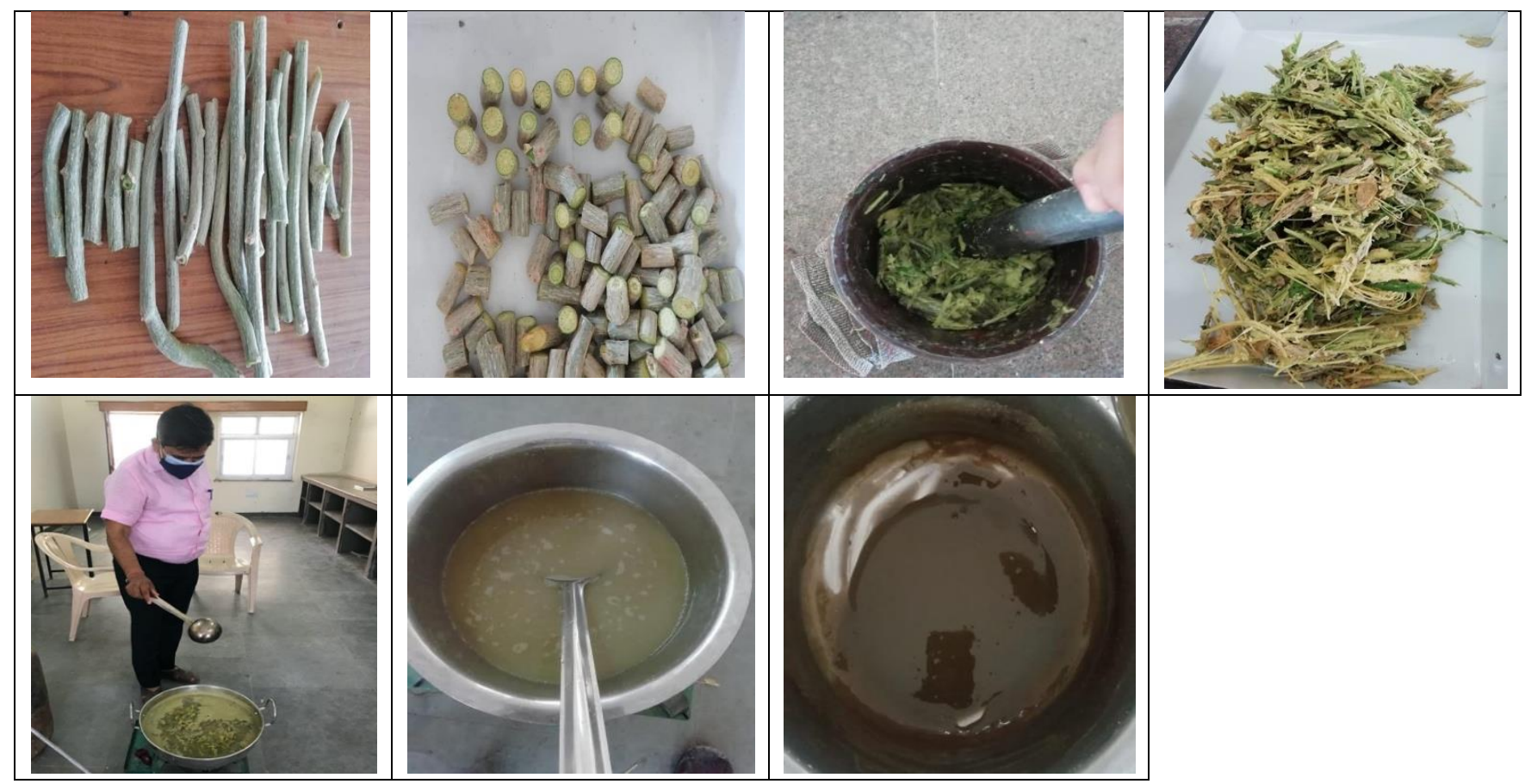

Guduchi Ghana Preparation

\section{REFERENCE}

1. Agnivesh, Charak Samhita, Chikitsa sthan 29/121, Revised by Charak and Dradhbala, Vidyotini Hindi Commentary edited by Pandit Kashinath Shastri and Dr Gorakhnath Chaturvedi, Chaukhamba Bharti Academy, Varanasi, pg 834.

2. Acharya Sushruta, Sushruta Samhita, Chikitsa sthan 9/7, Ayurveda Tatwa Sandipika Hindi Commentary by Kaviraj Ambikadutt Shastri, Chaukhmaba Sanskrit Sansthan, Varanasi, pg 63.

3. Chakrapanidutta, Chakradutta, Vaidyaprabha Hindi Commentary by Dr Indradev Tripathi, edited by Prof. Ramanath Dwivedi, Chapter 23/20, Chaukhamba Sanskrit Sansthan, Varanasi, pg 213.

4. Chakradutta, Vaidyaprabha Hindi Commentary by Dr Indradev Tripathi, edited by Prof. Ramanath Dwivedi, Chapter 23/20, Chaukhamba Sanskrit Sansthan, Varanasi, pg 214.
5. Sharangdhar, Sharangdhar Samhita, Pratham Khanda 1/45, Dipika Commentry by Adhamalla and Gudarth Dipika by Kasiram, edited by Parsurama Shastri, Chaukhamba orientalia, Varanasi, pg 11.

6. Sharangdhar Samhita, Madhyam Khanda 1/7, Dipika Commentry by Adhamalla and Gudarth Dipika by Kasiram, edited by Parsurama Shastri, Chaukhamba orientalia, Varanasi, pg 138.

7. Sharangdhar Samhita, Madhyam Khanda 9/3-4, Dipika Commentry by Adhamalla and Gudarth Dipika by Kasiram, edited by Parsurama Shastri, Chaukhamba Orientalia, Varanasi, pg 212.

8. Acharya Siddhinandan Mishra, Abhinava Bhaishjya Kalpana Vijnana, Chaukhamba Surbharti Prakashan, Varanasi, pg 163.

9. Prof. P.V. Sharma, Dravyaguna Vijnana, chapter 9, Chaukhamba Bharti Academy, Varanasi. pg 761, 762. 
10. Acharya Yadavji Trikamji, Siddha Yoga Sangrah, Baidhyanath Ayurveda Bhawan, Allahabad, pg 4

11. Upadhaya AK, Kumar K, Kumar A, MishraHS. Tinospora cordifolia (Willd.) Hook. F.and Thoms. (Guduchi)-Validation of the Ayurvedic pharmacology through experimental and clinical studies. Int J Ayurveda Res 2010; 1:112-121.

12. Patel MB, Mishra S. Hypoglycemic activity of alkaloidal fraction of Tinospora cordifolia. Phytomedicine 2011; 18:1045-1052.

13. Sriramaneni RN, Omar AZ, Zaini AM. The vasorelaxant effect of diterpenoid lactones from and Andrographis paniculata chloroform extraction rat aortic rings. Pharmacognosy Res 2010;2:242-246.

14. Dhanasekaran M, Baskar AA, Ignacimuthu S, Agastian P, Duraipandian V. Chemopreventive potential of Epoxy clerodane diterpene from Tinospora cordifolia against diethylnitrosamine induced hepatocellular carcinoma. Invest New Drugs 2009; 27:347-355.

15. Ly PT, Singh S, Shaw CA. Novel environmental toxins: Sheryl glycosides as a potential etiological factor for age-related neurodegenerative diseases. J Neurosci Res 2007; 85:231-237.)

16. Dr G. Prabhakar Rao, Bhaishjya Kalpana Vijnanam, Chapter 4, Chaukhamba Publication, New Delhi, Pg 136.

\section{Source of Support: Nil Conflict of Interest: None Declared}

How to cite this URL: Vijay Kumar Jatoliya et al: Preparation Of Aqueous Extract Of Tinospora Cordifolia (Wild) Miers Ex. Hook F. \& Thoms.: An Ayurveda Formulation. International Ayurvedic Medical Journal \{online\} 2021 \{cited August 2021\} Available from: http://www.iamj.in/posts/images/upload/1612_1617.pdf 